\title{
Effects of chloride, potassium, and sulfate on the causticizing reaction in the kraft recovery process
}

\author{
SONA SAEIDI, HONGHITRAN, AND VLADIMIROS G. PAPANGELAKIS
}

\begin{abstract}
We studied the effects of chloride $(\mathrm{Cl})$, potassium $(\mathrm{K})$, and sulfate $\left(\mathrm{SO}_{4}\right)$ on the equilibrium of the causticizing reaction over a wide range of causticizing conditions, using $\mathrm{OLI}$, an advanced thermodynamic program for equilibrium calculations in aqueous solutions of ionic salts. $\mathrm{Cl}, \mathrm{K}$, and $\mathrm{SO}_{4}$ were shown to have little or no effect on the causticizing equilibrium. Under a given causticizing condition, coastal mills, due to their much higher $\mathrm{NaCl}$ concentration, are predicted to have a causticizing efficiency $1 \%-2 \%$ lower than that of inland mills.
\end{abstract}

Application: Mills do not have to worry about the effect of chlorine, potassium, and sulfate on their causticizing plant performance.

n the causticizing plant of the kraft recovery process, caustic $(\mathrm{NaOH})$ is regenerated by reacting sodium carbonate $\left(\mathrm{Na}_{2} \mathrm{CO}_{3}\right)$ in green liquor with slaked lime $\left(\mathrm{Ca}(\mathrm{OH})_{2}\right)$ in the slaker, according to the reaction:

$\mathrm{Na}_{2} \mathrm{CO}_{3}+\mathrm{Ca}(\mathrm{OH})_{2}=2 \mathrm{NaOH}+\mathrm{CaCO}_{3}$

The causticizing reaction precipitates $\mathrm{CaCO}_{3}$ (lime mud), which is dewatered, washed, dried, and calcined in a lime kiln to produce lime $(\mathrm{CaO})$ for reuse in the slaker. The causticizing reaction is reversible so that the reaction rate decreases as more $\mathrm{NaOH}$ is produced. The reaction eventually stops when the system reaches equilibrium concentration of $\mathrm{NaOH}$. For given liquor system, the conversion of $\mathrm{Na}_{2} \mathrm{CO}_{3}$ into $\mathrm{NaOH}$ is often referred to as the causticizing efficiency (CE), which is defined as:

$$
\mathrm{CE}=\frac{[\mathrm{NaOH}]}{[\mathrm{NaOH}]+\left[\mathrm{Na}_{2} \mathrm{CO}_{3}\right]} \times 100
$$

where $[\mathrm{NaOH}]$ and $\left[\mathrm{Na}_{2} \mathrm{CO}_{3}\right]$ are concentrations of $\mathrm{NaOH}$ and $\mathrm{Na}_{2} \mathrm{CO}_{3}$ in the liquor system, expressed conventionally as $\mathrm{g} / \mathrm{L}$ $\mathrm{Na}_{2} \mathrm{O}$.

Causticizing efficiency has a direct impact on the quality of the white liquor produced and on the lime mud load in the lime kiln. Much work has been done over several decades to determine the thermodynamics and kinetics of the causticizing reaction, particularly the effects of liquor characteristics, i.e., sulfidity, total titratable alkali (TTA) and temperature on the causticizing equilibrium [1-5]. The effects of lime characteristics (i.e., lime type, particle size, composition, and degree of calcining) and reaction time on CE are also known [6-10]. In general, CE decreases with an increase in TTA, sulfidity, lime particle size, and the amount of impurities in lime, but increases with reaction temperature and time.

In addition to the main components, $\mathrm{Na}_{2} \mathrm{CO}_{3}, \mathrm{NaOH}$, and sodium sulfide $\left(\mathrm{Na}_{2} \mathrm{~S}\right)$, kraft liquor also contains minor components such as $\mathrm{Na}_{2} \mathrm{SO}_{4}, \mathrm{NaCl}$, and potassium salts. The concentrations of these water-soluble components vary greatly from mill to mill, and from boiler to boiler, depending on mill location, wood species, degree of mill closure, liquor sulfidity, types of makeup chemicals, as well as recovery boiler operating conditions [11]. Table I summarizes that, for inland softwood mills, the $\mathrm{Cl}$ and $\mathrm{K}$ concentrations in the green/white liquor are typically about $2.1 \mathrm{~g} / \mathrm{L} \mathrm{Cl}$ and $4.5 \mathrm{~g} / \mathrm{L} \mathrm{K}$, respectively. For hardwood mills, the potassium concentration is higher, $14 \mathrm{~g} / \mathrm{L} \mathrm{K}$, while for coastal mills, the $\mathrm{Cl}$ concentration is much higher, $12 \mathrm{~g} / \mathrm{L} \mathrm{Cl}$. The concentration ranges for $\mathrm{Cl}$ and $\mathrm{K}$ in both $\mathrm{g} / \mathrm{L}$ and mole $\%$ are also given.

The sulfate concentration in green and white liquors is typically $1.5-5 \mathrm{~g} / \mathrm{L} \mathrm{Na}_{2} \mathrm{SO}_{4}$ or $1-3.5$ mole $\% \mathrm{SO}_{4} /\left(\mathrm{Na}_{2}+\mathrm{K}_{2}\right)$. Sulfate concentration can be as high as $12 \mathrm{~g} / \mathrm{L} \mathrm{Na}_{2} \mathrm{SO}_{4}$ or 8.5 mole $\% \mathrm{SO}_{4} /\left(\mathrm{Na}_{2}+\mathrm{K}_{2}\right)$ for high sulfidity mills when the recovery boiler reduction efficiency is below $80 \%$.

Despite the presence of large amounts of $\mathrm{Cl}, \mathrm{K}$, and $\mathrm{SO}_{4}$ in green liquor, little is known about the effects of these species on the causticizing reaction. We performed a systematic study to examine how $\mathrm{Cl}, \mathrm{K}$, and $\mathrm{SO}_{4}$ may affect the causticizing equilibrium using a commercially available thermodynamic program. We describe the program and the simulation procedure, and discuss the key results obtained from the program predictions.

\section{THE PROGRAM AND SIMULATION PROCEDURE}

Modeling of the causticizing reaction $[12,13]$ focused generally on the kinetics of the reaction. For our study, we used an advanced thermodynamic program, OLI Stream Analyzer v. 2.0.31. The program is designed to calculate phase equilibri- 


\begin{tabular}{|l|l|c|c|c|c|}
\hline \multicolumn{2}{|c|}{} & \multicolumn{2}{c|}{ Inland mills } & \multicolumn{2}{c|}{ Coastal mills } \\
\cline { 3 - 6 } \multicolumn{2}{|c|}{} & Chpical & Range & Typical & Range \\
\hline Softwood & Chloride, g/L as Cl & 2.1 & $0.3-6.4$ & 12 & $8-14$ \\
\hline & Potassium, g/L as K & 4.5 & $2-7$ & 4.5 & $2-7$ \\
\hline Hardwood & Chloride, g/L as Cl & 2.1 & $0.3-6.4$ & 12 & $8-14$ \\
\hline & Potassium, g/L as K & 14 & $11-19$ & 14 & $11-19$ \\
\hline
\end{tabular}

\begin{tabular}{|c|c|c|c|c|c|}
\hline & & & & & nills \\
\hline & & Typical & Range & Typical & Range \\
\hline Softwood & Chloride, mole $\% \mathrm{Cl} /(\mathrm{Na}+\mathrm{K})$ & 1.4 & $0.2-4.2$ & 8 & $5-10$ \\
\hline & Potassium, mole $\% \mathrm{~K} /(\mathrm{Na}+\mathrm{K})$ & 2.8 & $1.3-4.5$ & 2.8 & $1.3-4.5$ \\
\hline Hardwood & Chloride, mole\% $\mathrm{Cl} /(\mathrm{Na}+\mathrm{K})$ & 1.4 & $0.2-4.2$ & 8 & $5-10$ \\
\hline & Potassium, mole $\% \mathrm{~K} /(\mathrm{Na}+\mathrm{K})$ & 8.5 & $6-11$ & 8.5 & $6-11$ \\
\hline
\end{tabular}

\section{Concentrations of $\mathrm{Cl}$ and $\mathrm{K}$ in green and white kraft liquors.}

um in aqueous solutions of ionic salts, and is mainly used to examine complex chemical and electrochemical phenomena in aqueous and mixed solvent solutions $[14,15]$. The program's thermodynamic model is based on published experimental data. It uses data regression where applicable, estimation and extrapolation where required, and is capable of predicting composition and concentration for ionic salt mixtures in water over a wide range of temperature, total pressure, and ionic strength. The program has been successfully used to predict the solubility of recovery boiler precipitator ash in water under various conditions [16], and the solubility of $\mathrm{PbSO}_{4}-\mathrm{NiSO}_{4}$ mixtures in the metallurgical and mining industries [17].

In our study, the input parameters to the program were the amounts of different species, as well as temperature and pressure. The main species considered were water, $\mathrm{Na}_{2} \mathrm{CO}_{3}$, $\mathrm{Ca}(\mathrm{OH})_{2}, \mathrm{Na}_{2} \mathrm{~S}, \mathrm{NaCl}, \mathrm{KCl}, \mathrm{K}_{2} \mathrm{CO}_{3}, \mathrm{Na}_{2} \mathrm{SO}_{4}, \mathrm{~K}_{2} \mathrm{SO}_{4}$ and $\mathrm{KCl}$. In cases where simulated or predicted values were to be compared with experimental data, the input parameters also included the temperature and pressure of the liquor system and those under which experiments were carried out. The program outputs were the concentrations of $\mathrm{Na}^{+}, \mathrm{K}^{+}, \mathrm{OH}^{-}, \mathrm{S}^{-2}$, $\mathrm{HS}^{-}, \mathrm{CO}_{3}^{-2}, \mathrm{SO}_{4}^{-2}, \mathrm{Cl}^{-}$, etc. in the solution, and the amounts of precipitated $\mathrm{CaCO}_{3}$ as well as un-reacted $\mathrm{Ca}(\mathrm{OH})_{2}$. The concentrations were used to calculate the concentrations of the main species, causticizing efficiency (CE), according to Eq.1, total titratable alkali (TTA), and sulfidity of the liquor, which are defined in Eq. 3 and Eq. 4 as:

TTA $=[\mathrm{NaOH}]+\left[\mathrm{Na}_{2} \mathrm{~S}\right]+\left[\mathrm{Na}_{2} \mathrm{CO}_{3}\right]$

Sulfidity $=\frac{\left[\mathrm{Na}_{2} \mathrm{~S}\right]}{\mathrm{TTA}} \times 100$

where $[\mathrm{NaOH}],\left[\mathrm{Na}_{2} \mathrm{~S}\right]$ and $\left[\mathrm{Na}_{2} \mathrm{CO}_{3}\right]$ are concentrations of $\mathrm{NaOH}, \mathrm{Na}_{2} \mathrm{~S}$ an, $\mathrm{Na}_{2} \mathrm{CO}_{3}$, in the solution, all expressed as $\mathrm{g} / \mathrm{L}$ $\mathrm{Na}_{2} \mathrm{O}$.

To evaluate the suitability of the program in predicting $\mathrm{CE}$, we used the program first to predict the causticizing equilibrium (or maximum $\mathrm{CE}$ ) of pure systems that contain only $\mathrm{Na}_{2} \mathrm{CO}_{3}, \mathrm{Na}_{2} \mathrm{~S}, \mathrm{Ca}\left(\mathrm{OH}_{2}\right)$, and water, as a function of TTA and sulfidity. We compared the predicted results with ex- perimental data obtained from the literature and with the data obtained from selected experiments we performed. We then used the tested program to examine the effects of $\mathrm{Cl}, \mathrm{K}$, and $\mathrm{SO}_{4}$ on $\mathrm{CE}$.

\section{PROGRAM EVALUATION}

\section{CE equilibrium for a pure $\mathrm{Na}_{2} \mathrm{CO}_{3}$ solution}

Figure 1 shows the $\mathrm{CE}$ predicted by the program (solid curve) for the pure $\mathrm{Na}_{2} \mathrm{CO}_{3}$ system at $90^{\circ} \mathrm{C}$, with a $\mathrm{Na}_{2} \mathrm{CO}_{3}$ to $\mathrm{Ca}(\mathrm{OH})_{2}$ molar ratio of 1.25 , as a function of TTA. The predicted $\mathrm{CE}$ is the maximum attainable $\mathrm{CE}$ for the system. The results are in reasonable agreement with experimental data obtained by various research groups that show the equilibrium CE decreases as TTA increases. We obtained the experimental data noted as open circles under well-controlled test conditions at $90^{\circ} \mathrm{C}$ for $1 \mathrm{~h}$. The results were consistent with, but about 1\%-3\% lower than, the prediction results and literature data $[1,4,5]$. The lower experimental values we obtained suggest that the system may not have yet reached equilibrium.

\section{CE of $\mathrm{Na}_{2} \mathrm{CO}_{3}-\mathrm{Na}_{2} \mathrm{~S}$ solutions}

The program also simulated the $\mathrm{CE}$ of liquors containing both $\mathrm{Na}_{2} \mathrm{CO}_{3}$ and $\mathrm{Na}_{2} \mathrm{~S}$. We performed the simulations at three sulfidity levels, $0 \%, 15 \%$, and 30\%, which have been frequently cited in textbooks [18, 19]. Figure 2 shows the predicted results

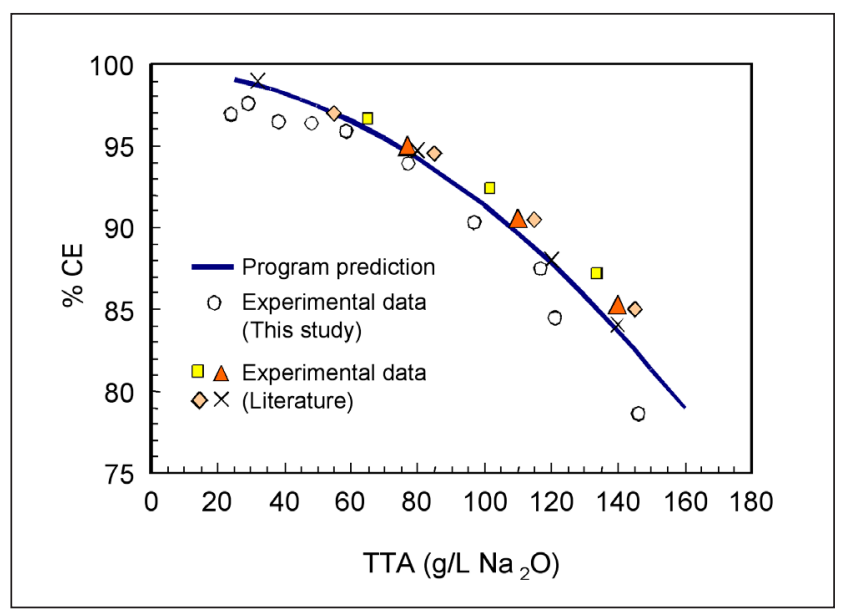

1. Effect of TTA on the maximum attainable $\mathrm{CE}$ at $90^{\circ} \mathrm{C}$ for pure $\mathrm{Na}_{2} \mathrm{CO}_{3}$ solutions with a $\mathrm{Na}_{2} \mathrm{CO}_{3} / \mathrm{Ca}(\mathrm{OH})_{2}$ molar ratio of 1.25 . 


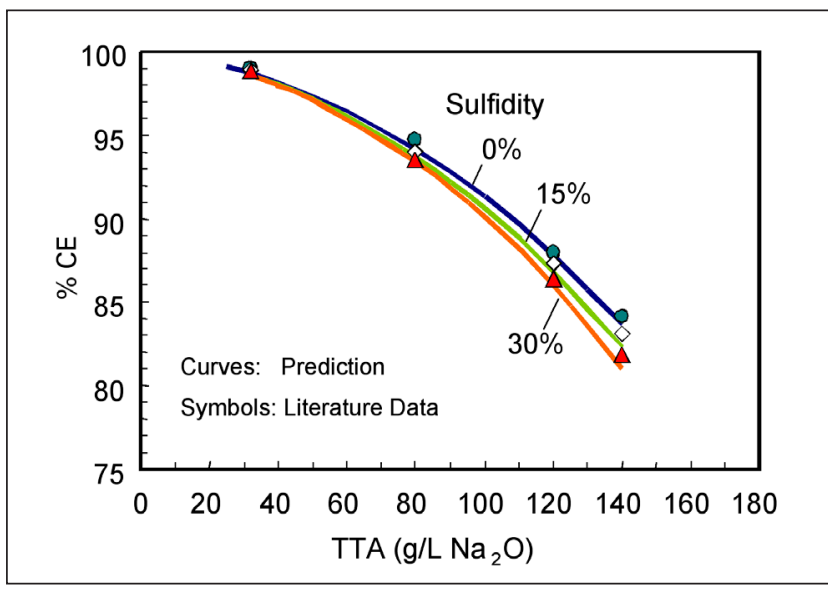

2. Effect of $\mathrm{Na}_{2} \mathrm{~S}$ on equilibrium $\mathrm{CE}$ at $90^{\circ} \mathrm{C}$ and $\mathrm{Na}_{2} \mathrm{CO}_{3}\left(\mathrm{Ca}(\mathrm{OH})_{2}\right.$ molar ratio of 1.25 .

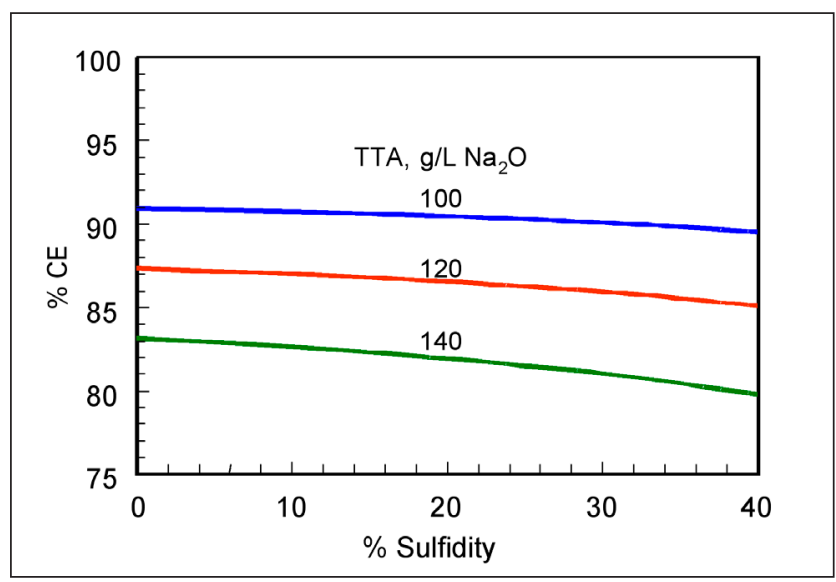

3. Effect of sulfidity on equilibrium $\mathrm{CE}$ at $90^{\circ} \mathrm{C}$ and $\mathrm{Na}_{2} \mathrm{CO}_{3}$ / $\mathrm{Ca}(\mathrm{OH})_{2}$ molar ratio of 1.25 .

(curves), along with literature data (data points) obtained at selected TTA levels. In all cases, there was good agreement between predicted values and literature data. At each sulfidity level, the equilibrium CE decreases with an increase in TTA, while at a given TTA, CE, decreases with an increase in sulfidity.

We also examined the effect of sulfidity on the equilibrium $\mathrm{CE}$ at three TTA values: 100,120 , and $140 \mathrm{~g} / \mathrm{L} \mathrm{Na} \mathrm{N}_{2} \mathrm{O}$. We chose these values because they cover the typical TTA range of 120 $\mathrm{g} / \mathrm{L} \mathrm{Na} \mathrm{O}_{2} \pm 20 \mathrm{~g} / \mathrm{L} \mathrm{Na} \mathrm{O}_{2} \mathrm{O}$. Figure 3 shows these predictions. While increasing sulfidity results in a lower equilibrium CE, the effect is much smaller than that of TTA. At TTA=120 g/L $\mathrm{Na}_{2} \mathrm{O}$, for example, increasing sulfidity from $25 \%$ to $40 \%$ will result in a decrease in the equilibrium CE of only about $1 \%$.

\section{EFFECT OF POTASSIUM}

To test the accuracy of the program in predicting the equilibrium $\mathrm{CE}$ of systems that contain $\mathrm{K}$, we performed simulations and experiments on solutions of $\mathrm{Na}_{2} \mathrm{CO}_{3}$ mixed with either $10 \mathrm{wt} \% \mathrm{~K}_{2} \mathrm{CO}_{3}, 10 \mathrm{wt} \% \mathrm{KCl}$, or $10 \mathrm{wt} \% \mathrm{~K}_{2} \mathrm{SO}_{4}$. Figure 4 shows these results. The predicted CE values were $2 \%-4 \%$ higher than the experimental values, presumably due to incomplete causticization during the 1 -h experiments. The trend, however, was consistent in all cases, suggesting that the program can be applied to systems that contain K. Since
CHEMICAL RECOVERY

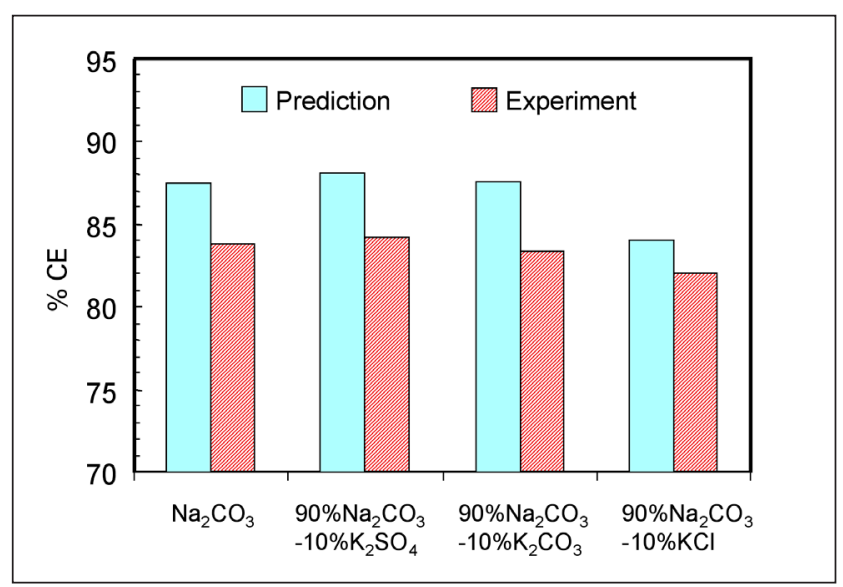

4. Effect of potassium on equilibrium $\mathrm{CE}$ at $90^{\circ} \mathrm{C}, 0 \%$ sulfidity, $120 \mathrm{~g} \mathrm{Na}_{2} \mathrm{O} / \mathrm{L} \mathrm{TTA}, \mathrm{Na}_{2} \mathrm{CO}_{3} / \mathrm{Ca}(\mathrm{OH})_{2}$ molar ratio of 1.25.

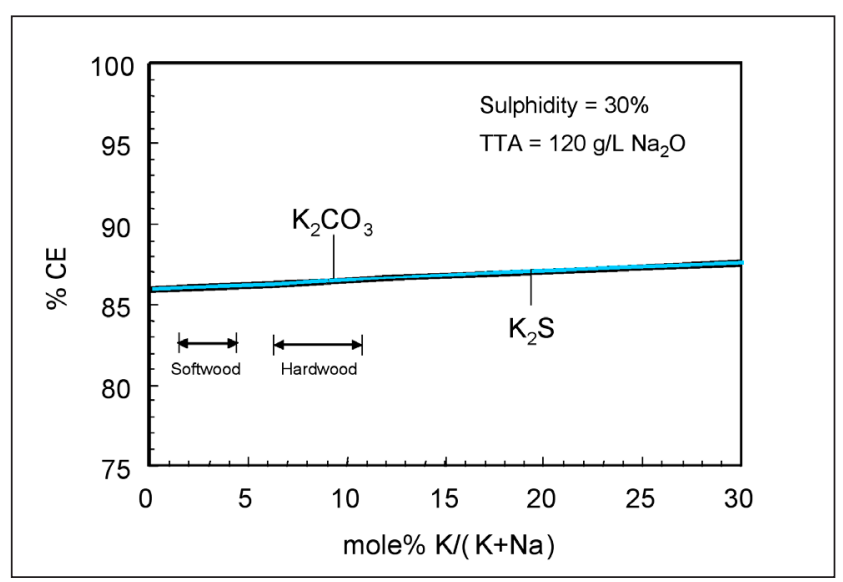

5. Comparison between the effects of $\mathrm{K}_{2} \mathrm{CO}_{3}$ and $\mathrm{K}_{2} \mathrm{~S}$ on the predicted equilibrium $\mathrm{CE}, \mathrm{TTA}=120 \mathrm{~g} / \mathrm{L} \mathrm{Na}{ }_{2} \mathrm{O}, 30 \%$ sulfidity.

the potassium compounds in the green liquor before causticizing are mainly $\mathrm{K}_{2} \mathrm{CO}_{3}, \mathrm{~K}_{2} \mathrm{~S}, \mathrm{KCl}$, and $\mathrm{K}_{2} \mathrm{SO}_{4}$, we examined the effect of these compounds on CE.

\section{$\mathrm{K}_{2} \mathrm{CO}_{3}$ and $\mathrm{K}_{2} \mathrm{~S}$}

Since carbonate $\left(\mathrm{CO}_{3}^{-2}\right)$ and sulfide $\left(\mathrm{S}^{-2}\right)$ are the major anions in green liquor, the effects of $\mathrm{K}$ on $\mathrm{CE}$ were first studied by substituting $\mathrm{Na}_{2} \mathrm{CO}_{3}$ and $\mathrm{Na}_{2} \mathrm{~S}$ in the liquor with $\mathrm{K}_{2} \mathrm{CO}_{3}$ and $\mathrm{K}_{2} \mathrm{~S}$, respectively. We then compared the effect of $\mathrm{K}_{2} \mathrm{CO}_{3}$ with that of $\mathrm{Na}_{2} \mathrm{CO}_{3}$ by replacing $\mathrm{Na}_{2} \mathrm{CO}_{3}$ with $\mathrm{K}_{2} \mathrm{CO}_{3}$, while the effect of $\mathrm{K}_{2} \mathrm{~S}$ was compared with that of $\mathrm{Na}_{2} \mathrm{~S}$ by replacing $\mathrm{Na}_{2} \mathrm{~S}$ with $\mathrm{K}_{2} \mathrm{~S}$.

Figure 5 presents the simulation results for both $\mathrm{K}_{2} \mathrm{CO}_{3}$ and $\mathrm{K}_{2} \mathrm{~S}$ for the typical liquor sulfidity of $30 \%$ and TTA of 120 $\mathrm{g} / \mathrm{L} \mathrm{Na} \mathrm{N}_{2} \mathrm{O}$. In both cases, the results are the same. As the $\mathrm{K}$ concentration in the liquor increases, CE increases slightly. We observed similar results at lower sulfidity levels, $0 \%$ and $15 \%$ (not shown). Since the potassium concentration in the liquor varies between 1.3 and $11 \mathrm{~mole} \% \mathrm{~K} /(\mathrm{Na}+\mathrm{K}$ ) (see Table 1), the results indicate that increasing the potassium concentration in the liquor will cause, at the most, a $0.5 \%$ increase in the equilibrium CE. 


\section{$\mathrm{KCl}$ and $\mathrm{K}_{2} \mathrm{SO}_{4}$}

In the case of $\mathrm{K}_{2} \mathrm{CO}_{3}$ and $\mathrm{K}_{2} \mathrm{~S}$ shown in Fig. 5, it was possible to increase the $\mathrm{K}^{+}$concentration and keep the concentrations of $\mathrm{CO}_{3}{ }^{2-}$ and $\mathrm{S}^{2-}$ constant at the same time, by simply substituting $\mathrm{Na}_{2} \mathrm{CO}_{3}$ and $\mathrm{Na}_{2} \mathrm{~S}$ in the liquor with the same number of moles of $\mathrm{K}_{2} \mathrm{CO}_{3}$ and $\mathrm{K}_{2} \mathrm{~S}$, respectively. However, this was not possible in the case of $\mathrm{KCl}$ and $\mathrm{K}_{2} \mathrm{SO}_{4}$, since there was no $\mathrm{NaCl}$ or $\mathrm{Na}_{2} \mathrm{SO}_{4}$ in the initial liquor (which contained only $\mathrm{Na}_{2} \mathrm{CO}_{3}$ and $\mathrm{Na}_{2} \mathrm{~S}$ ) to substitute for. As a result, adding $\mathrm{KCl}$ and $\mathrm{K}_{2} \mathrm{SO}_{4}$ to the system would increase the $\mathrm{K}^{+}$concentration and the $\mathrm{Cl}$ and $\mathrm{SO}_{4}{ }^{2-}$ concentrations.

Figure $\mathbf{6}$ shows the effect of $\mathrm{K}$ on the predicted equilibrium CE obtained by adding $\mathrm{KCl}$ and $\mathrm{K}_{2} \mathrm{SO}_{4}$ to the liquor, as predicted by the program. Increasing $\mathrm{K}$ by adding $\mathrm{K}_{2} \mathrm{SO}_{4}$ does not appreciably change $\mathrm{CE}$, while increasing $\mathrm{K}$ by adding $\mathrm{KCl}$ decreases it. Note that at a given mole $\% \mathrm{~K} /(\mathrm{Na}+\mathrm{K})$, the $\mathrm{K}^{+}$concentration in the system is the same for both $\mathrm{K}_{2} \mathrm{SO}_{4}$ and $\mathrm{KCl}$. Therefore, the difference between the effects of these two potassium salts on $\mathrm{CE}$ is likely caused by the anions, either $\mathrm{Cl}^{-}$or $\mathrm{SO}_{4}^{2-}$, and the effect of $\mathrm{Cl}$ is much greater than that of $\mathrm{SO}_{4}^{2}$.

\section{EFFECT OF GHLORIDE}

The chloride compounds considered were $\mathrm{KCl}$ and $\mathrm{NaCl}$. The simulation procedure for $\mathrm{KCl}$ was the same as that described in the previous section, since in this case the mole $\% \mathrm{~K} /(\mathrm{Na}+\mathrm{K})$ is exactly the same as the mole $\% \mathrm{Cl} /(\mathrm{Na}+\mathrm{K})$. In the case of $\mathrm{NaCl}$, the procedure was also the same, except that $\mathrm{NaCl}$ was used instead of $\mathrm{KCl}$.

Figure 7 shows the effect of $\mathrm{Cl}$ on the predicted equilibrium CE of a liquor system with $120 \mathrm{~g} / \mathrm{L} \mathrm{Na} \mathrm{N}_{2} \mathrm{O}$ TTA and $30 \%$ sulfidity. We observed a similar trend for both $\mathrm{NaCl}$ and $\mathrm{KCl}$, suggesting that the presence of $\mathrm{Cl}$ lowers $\mathrm{CE}$, and that $\mathrm{NaCl}$ has a slightly greater effect than $\mathrm{KCl}$. This adverse effect of $\mathrm{NaCl}$ on causticizing has also been reported in the literature.

\section{EFFECT OF SULFATE}

Figure 8 shows the simulation results for $\mathrm{Na}_{2} \mathrm{SO}_{4}$ and $\mathrm{K}_{2} \mathrm{SO}_{4}$. In both cases, the predicted equilibrium $\mathrm{CE}$ remains relative-

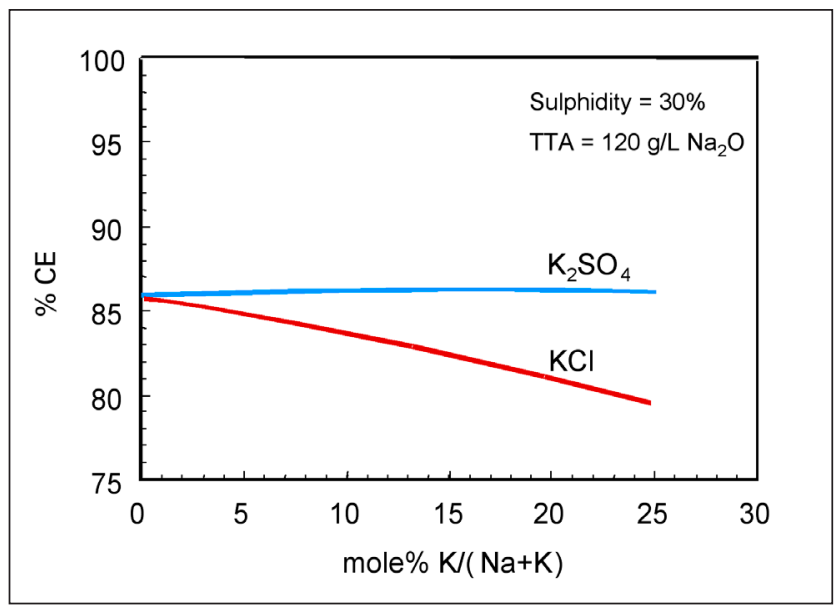

6. Comparison of the effects of $\mathrm{K}_{2} \mathrm{SO}_{4}$ and $\mathrm{KCl}$ on the predicted equilibrium CE, $T T A=120 \mathrm{~g} / \mathrm{L} \mathrm{Na} 2 \mathrm{O}, 30 \%$ sulfidity.

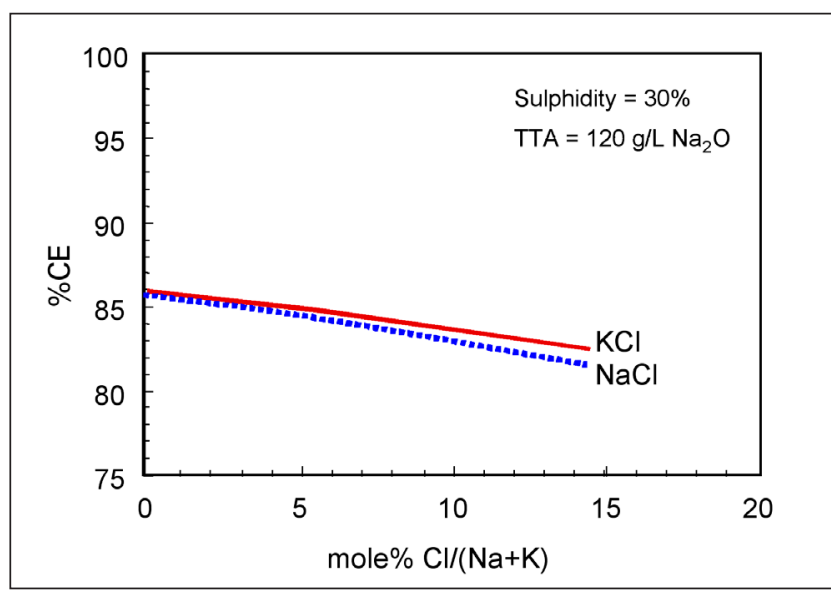

7. Comparison of the effect of $\mathrm{KCl}$ and $\mathrm{NaCl}$ on the predicted equilibrium CE, $T T A=120 \mathrm{~g} / \mathrm{L} \mathrm{Na}{ }_{2} \mathrm{O}, 30 \%$ sulfidity.

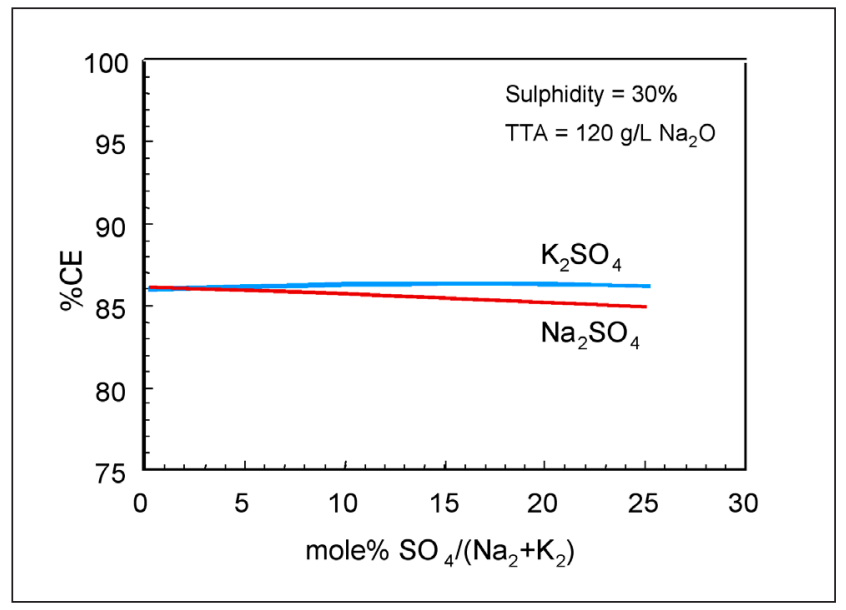

8. Comparison of the effects of $\mathrm{K}_{2} \mathrm{SO}_{4}$ and $\mathrm{Na}_{2} \mathrm{SO}_{4}$ on the predicted equilibrium $C E, T T A=120 \mathrm{~g} / \mathrm{L} \mathrm{Na20}, 30 \%$ sulfidity.

ly constant as the $\mathrm{SO}_{4}$ concentration increases. $\mathrm{K}_{2} \mathrm{SO}_{4}$ appears to have a slightly positive effect, while $\mathrm{Na}_{2} \mathrm{SO}_{4}$ appears to have a slightly negative effect. Since the $\mathrm{SO}_{4}$ concentration in the green liquor is typically lower than $3.5 \mathrm{~mole} \% \mathrm{SO}_{4} /\left(\mathrm{Na}_{2}+\mathrm{K}_{2}\right)$, and would not exceed 9 mole $\% \mathrm{SO}_{4} /\left(\mathrm{Na}_{2}+\mathrm{K}_{2}\right)$ even in the worst case scenario of high sulfidity $(>40 \%)$ and low reduction efficiency $(<75 \%)$, we can conclude that $\mathrm{SO}_{4}$ does not have any practical effect on CE.

The above results clearly show that varying $\mathrm{K}^{+}$and $\mathrm{SO}_{4}{ }^{2-}$ concentrations would not cause appreciable change in the equilibrium $\mathrm{CE}$, while increasing the $\mathrm{Cl}$ concentration would adversely affect the $\mathrm{CE}$. The results are plausible since $\mathrm{K}^{+}$and $\mathrm{Na}^{+}$have the same charge (+1), while $\mathrm{Cl}$ has a different charge $(-1)$, compared to $\mathrm{SO}_{4}{ }^{2-}$ and $\mathrm{CO}_{3}{ }^{2-}(-2)$.

\section{CONGLUSIONS}

The effects of chloride $(\mathrm{Cl})$, potassium $(\mathrm{K})$, and sulfate $\left(\mathrm{SO}_{4}\right)$ on the equilibrium of the causticizing reaction $\mathrm{Na}_{2} \mathrm{CO}_{3}+$ $\mathrm{Ca}(\mathrm{OH})_{2}=2 \mathrm{NaOH}+\mathrm{CaCO}_{3}$ were studied using an advanced thermodynamic program by OLI Systems. The simulation results suggest that: 
- Although $\mathrm{Cl}$ has an adverse effect on CE, in any given kraft pulp mill, the variations in $\mathrm{Cl}$ concentration are not large enough to cause any practical effect on CE. However, since the $\mathrm{Cl}$ concentration in the green and white liquors in coastal mills are 2-4 times higher than those in inland mills, coastal mills are predicted to have a CE $1 \%-2 \%$ lower than that of inland mills.

- While K may cause a slight increase in CE, within the typical concentration range of $\mathrm{K}$ in the liquor system, the effect is insignificant.

- $\mathrm{SO}_{4}$ has little or no practical effect on the equilibrium CE.

Received: March 6, 2008

Revised: August 6, 2008

Accepted: August 20, 2008

\section{ACKNOWLEDGEMENTS}

This work was part of the research program on Increasing Energy and Chemical Recovery Efficiency in the Kraft Process. The program is jointly supported by the Natural Sciences and Engineering Research Council of Canada (NSERC) and a consortium of the following companies: Abitibi-Bowater, Alstom Power, Andritz, Aracruz Celulose, Babcock \& Wilcox, Boise, Celulose Nipo-Brasileira, Carter Holt Harvey, ClydeBergemann, Diamond Power International, Domtar, DMI Peace River Pulp, Georgia Pacific, International Paper, Irving Pulp \& Paper, Metso Power, MeadWestvaco, Stora Enso Research, Tembec, and Votorantim Celulose e Papel.

\section{LITERATURE CITED}

1. Goodwin, L.F., J. Soc. Chem. Ind., 10: 360T(1926).

2. Goodwin, L.F. and Sills, I.L., J. Soc. Chem. Ind., 10: 362T(1926).

3. Kobe, K.A. and Wilkinson, J. A., J. Ind. and Eng. Chem., 45(2): 307(1953).
4. Littman, F.E. and Gaspari, H.J., J. Ind. and Eng. Chem., 48(3): 408(1956).

5. Ransdell, J.C. and Genco, J.M., TAPPI J., 74(8): 169(1991).

6. Grigoryan, G.0. and Movsesyan, M.S., Zhurnal Prikladnoi Khimii (translated), 42(11): 2409(1969).

7. Dorris, G.M. and Allen, L.H., J. Pulp Paper Sci., 11(4): J89(1985).

8. Dorris, G.M., J. Pulp Paper Sci., 19(6): J256(1993).

9. Lindberg, H. and Ulmgren, P., TAPPI J., 69(3): 126(1986).

10. Konno, H., Nanri, Y., Kitamura, M., Powder Tech., 123(11): 33(2002).

11. Tran, H.N., Barham, D., Reeve, D. W., Pulp Paper Can., 91(5): $55(1990)$.

12. Wang, L., Tessier, P., Englezos, P., TAPPI J., 77(12): 95(1994).

13. Sethuraman, J., Krishnagopalan, J., Krishnagopalan, G., TAPPI J., 78(1): 115(1995).

14. http://www.olisystems.com

15. Wang, P., Anderko, A., Young, R.D., Fluid Phase Equilibria, 203: 141(2002).

16. Saturnino, D. and Tran, H.N., "Prediction of the solubility of recovery boiler precipitator ash," 2007 TAPPI Engineering, Pulping and Environmental Conference Proceedings, TAPPI PRESS, Atlanta, GA, USA.

17. Liu, H. and Papangelakis, V.G., Ind. and Eng. Chem. Res., 45(1): $39(2006)$

18. Cornell, C.F., "Cooking Liquor Preparation," in Chemical Recovery in the Alkaline Pulping Processes, 3rd edn., TAPPI PRESS, Atlanta, GA, USA, 1997.

19. Grace, T.M. and Malcolm, E.W., "Preparation of White Liquor," Pulp and Paper Manufacture, Vol. 5 Alkaline Pulping, 3rd ed., Joint Textbook Committee of the Paper Industry, TAPPI/CPPA, Atlanta/Montreal, p. 568 (1989).

\section{INSIGHTS FROM THE AUTHORS}

Although there has been much speculation about the effects of chloride, potassium, sulfate, and other nonprocess elements on causticizing equilibrium, the effects have not been systematically examined. Our work complements our research on chemical recovery, particularly our understanding of the effects of chloride, potassium, and sulfate in the causticizing plant.

Our most difficult challenge was to obtain sufficient experimental data on the causticizing reaction to validate our OLI base-thermodynamic model. We addressed it by performing numerous experiments in our laboratory and by conducting an extensive literature survey.

Our most interesting finding was that despite all the concerns, chloride, potassium, and sulfate have little effect on causticizing equilibrium. Mills no longer have to worry about the effect of the elements on their causticizing plant performance.

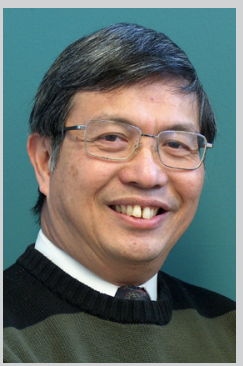

Tran

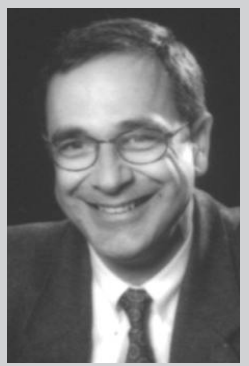

Papangelakis
Saeidi

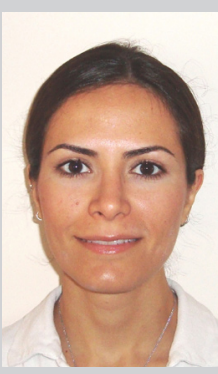

Tran is Frank Dottori Professor of Pulp \& Paper Engineering, Department of Chemical Engineering and Applied Chemistry, and Director, Pulp \& Paper Center, University of Toronto, Toronto, ON, Canada. Papangelakis is a professor and Saeidi is a graduate student, University of Toronto, Toronto, ON, Canada. Email Tran at honghi.tran@utoronto.ca. 